Grácio, R., Coutinho, A. C., Falé, L. \& Sobreira, M. (2020). The Art of Feminist-Queering the Museum: Gate-leaking, Museum International, 72 (3-4), DOI:

https://doi.org/10.1080/13500775.2020.1873522

\title{
The Art of Feminist-Queering the Museum: Gate-leaking
}

\section{Abstract}

This paper takes part in the ongoing debate around how museums have begun to address LGBTQI+ and feminist issues in the $21^{\text {st }}$ century. While Portugal is a particularly interesting country to consider, given that it has passed some of the most advanced legislation on LGBTQI+ rights in Europe (Santos, 2012), this progressivism is not reflected in Portuguese museum practices, given that gender museology has been slow to emerge (Vaquinhas, 2014).

After briefly contextualising initiatives addressing gender in Portuguese art museums, we present as a case study Bringing the margin to the centre, a series of three talks hosted by the Berardo Collection Museum, which is considered Portugal's primary modern and contemporary art museum. Unlike previous initiatives in art museums, which were museum-led, the series of talks was led by the small intersectional feminist collective FACA.

A sociologist (Rita Grácio) and three members of FACA (Andreia Coutinho, Laura Falé and Maribel Sobreira) designed and conducted the three talks that constitute the initiative Bringing the margin to the centre. Grácio designed and conducted the qualitative study of the audiences that attended Bringing the margin to the centre. This study consisted of participant observation at the event series, at which an adapted version of the Personal Meaning Mapping technique (Falk \& Storksdieck, 2005) was applied; semi-structured phone interviews with participants were then conducted after the event (Falk \& Dierking, 2011). The main findings show this event raised awareness among cisgender visitors with heteronormative perspectives and provided a space for counter-narratives of the queer community, showing the role of collective curatorial activism and museums in promoting gender equality and inclusiveness, if acting as gate-leakers, rather than as gatekeepers. Hence, museums can provide lessons to other organisations interested in promoting diversity and inclusion.

Keywords: art museum, collective curatorial activism, queer narratives, museum audiences, inclusive organisations 


\section{Introduction}

This article takes part in the debate around how museums have begun to address LGBTQI+ (Lesbian, Gay, Bisexual, Transgender, Queer, Intersex, and others who identify as part of this community) and feminist issues in the $21^{\text {st }}$ century. For this purpose, it draws on the case of art museums in Portugal, and how they have addressed those issues. Portugal is a particularly interesting country to engage in this debate, given it has some of the most advanced legislation on LGBTQI+ rights in Europe (Santos, 2012). However, the slow and shy emergence of gender museology (Vaquinhas, 2014), shows that this legal advancement is not reflected in museum practices.

In this context, we present the FACA collective ${ }^{1}$ and the event they designed, which attempted to bring queer, postcolonial and feminist discussions into museums. This event at the Berardo Collection Museum (which we will refer to as Berardo Museum, interchangeably) consisted of three talks, under the name Bringing the margin to the centre. Berardo Museum, located in Lisbon, in the facilities of the Centro Cultural de Belém, is hailed as the main modern and contemporary art museum in Portugal. After situating the context, we present the study and the participants. We used participant observation, Personal Meaning Mapping (PMM) and interviews as methods to collect data, which were analysed thematically. The focus of this article will be on the second talk, entitled 'Queer identities at Berardo Museum'. This is also the title of the section that details the data analysis, followed by its discussion. This article provides a case study on 'how to' queer the museum, from the perspective of curatorial activists and audiences, in an art museum in Lisbon. Finally, we show how this case study can offer valuable lessons on diversity and inclusion to other organisations.

\section{Feminism, queerness and postcolonialism at the art museum}

The history of European museums cannot be separated from the history of the European colonial project, grounded in assumptions of Western superiority, racial hegemony, the construction of the nation state and othering (Modest, 2012). The debate in 2019 at ICOM's General Conference in Kyoto over the proposed definition of a museum for the $21^{\text {st }}$ century, as presented by ICOM, is a vivid reminder of the epistemic, sociopolitical and ethical struggles which persist, embedded in museums (Sandahl, 2019).

To think of museums in the 21st century is not forgoing museums' roots. Gender and racial/ethnic inequalities persist. On the one hand, there is an underrepresentation of women and minorities, especially non-white women and LGBTQI+, in museum collections and exhibitions (Brulon, 2019). On the other hand, even if the museum sector has become feminised, neither women nor minorities have a place at the top of the hierarchy_there is a clear glass ceiling (Baldwin \& Ackerson, 2017) - and minorities are underrepresented in museum audiences (Lussenhop, 2018).

How can museums become more inclusive and diverse? We aim to look at museums' initiatives that made actors, who have traditionally been marginalised, visible; these initiatives can help to see the museum through a queer lens, resisting the reproduction of white, patriarchal, cisgender heteronormativities. 
Gender museology has allowed the uncovering of the negative effects of white heterosexual male domination, which has rendered some women and other minorities' (art)work invisible throughout history (Brulon, 2019). Efforts have been made to represent LGBTQI+ history in museums. Chantraine (2017) shows two ways of queering the museum collections_emphasising that 'queering' and 'museum collections' are not mutually exclusive. The first is community-based, counting on LGBTQI+ organisations as facilitators, and aiming to make this community visible in museums. The second one, more radical and more theoretical, implies a reflection on how the museum participates in the construction of a heteronormative system, including not only gender but also social class, race/ethnicity and other lines of inequalities.

Portugal is an interesting context within which to debate these issues. It has some of the most advanced legislation on LGBTQI+ rights in Europe (Santos, 2012), and has an institutional feminism equality mechanism-the state's Commission for Citizenship and Gender Equality (CIG). However, these state practices at the legal and institutional level do not resonate with museological practice, although most museums in Portugal are state museums.

Women and minorities have often remained invisible in museums' exhibitions and discourses. As in other countries, there is a strong feminisation of museum professionals in Portugal (Vaquinhas, 2014); unlike in other countries, however, white women are more likely to reach top positions, such as that of museum director, although they still don't make up the majority of museum directors throughout Portugal. Despite this progress, minorities are still underrepresented, either in displays or in the museum workplace-except for the contingent of Black women who clean the Portuguese museums.

The international debate on the decolonisation of museums arrived in Portugal in 2018, following a campaign pledge to build a museum in Lisbon dedicated to Portugal's colonial history (Ribeiro, 2018)—which was rejected, but sparked debate in this racialised country (Abrantes \& Roldão, 2019). Long before that, an afrodescendants' civil society organisation (DJASS), led by women, advocated for a memorial to enslaved people. Through the 2017/2018 edition of Lisbon's Participatory Budgeting programme, this project successfully received its funding ${ }^{2}$. Apart from this initiative, and the controversial debate in the civil society and within the museum community, we are not aware of any changes towards decolonising museums in Portugal.

The integration of a gender perspective in contemporary museology has been slow. In the field of gender museology, whose roots are indebted to Moutinho's sociomuseology (Moutinho, 2019), we highlight the pioneering work of Aida Rechena, whose doctoral thesis analysed the images of women in museum exhibitions (Rechena, 2013), and won an APOM (Portuguese Association of Museology) prize. Later on, and as the director of the National Museum of Contemporary Art (Museu do Chiado, MNAC) in Lisbon, Aida Rechena, together with Teresa Veiga Furtado, promoted an action-research project between museums and fine arts schools. This project culminated in the temporary exhibition Gender in Art: Body, sexuality, identity and resistance at MNAC, between October 2017 and March 2018. The exhibition relied on participatory curatorship, and the project targeted students and surrounding communities, aiming to change these audience's attitudes through art (Rechena \& Furtado, 2019). This project was awarded the 2018 Best Work in Museology, by APOM. ILGA-PORTUGAL also recognised this project, awarding MNAC the 2017 prize Rainbow - Equality in Culture. 
In the same year, this prize was also awarded to the Gulbenkian Museum for organising 'The Gulbenkian collection comes out of the golden closet? Queer narratives in the Gulbenkian Collection', a 2017 guided tour by the guest curator Michael Langan. This tour was integrated into the PRIDE Week - Lisbon. The Gulbenkian Museum opened the 'Feminist tour' in May 2019. Penelope Curtis, former director of Tate Britain, and director of Museum Calouste Gulbenkian (2015-2020), stated that 'the museum is trying to normalise the presence of women' (Cardoso, 2019).

LGBTQI+ archives and heritage are relevant. However, the main bulk of this work is undertaken by LGBTQI+ associations and scholar-activists (Cascais, 2004; Alcaire, 2019), not in tandem with museums. Others have pointed to the exclusion of the LGBTQI+ agenda from the museological space (Baptista \& Boita, 2017). In 2018, the European Year of Cultural Heritage, Acesso Cultura's annual conference organised a powerful debate on LGBTQI+ heritage. The conference gathered academics, LGBTQI+ organisations, activists, museum professionals, curators, artists, educators, cultural managers. In the wake of this conference, Acesso Cultura organised a seminar on Museums and Gender, where the organisers of both Gender in art and 'The Gulbenkian Collection comes out of the Golden Closet' presented their work.

This brief overview paves the way to contextualise how the curatorial activism of FACA which brought together the topics of feminism, postcolonialism and queerness to one of the main private modern and contemporary art museums in Portugal - stands as a singular project in the Portuguese museum landscape.

\section{FACA: Opening the 'wounds' of artworks through collective curatorial activism}

The FACA collective is an active citizenship project and intersectional feminist collective, composed of three people with backgrounds in museum studies and aesthetics. It is formed by three of the co-authors of this paper: Andreia Coutinho, Laura Falé, and Maribel Sobreira .

Starting in 2019, FACA proposed a three-talk series called Bringing the margin to the centre, which consisted of three talks/conversations on feminism, queerness and postcolonialism centred on the Berardo Museum's permanent and temporary exhibitions. The first talk, with the eponymous title 'Bringing the margins to the centre', functioned as an introduction to all of the topics (May 2019). The second talk focused on queerness (June 2019), and the third talk on feminism (March 2020). Knowing that these issues are being discussed internationally, and following the \#metoo movement, FACA aimed to bring these discussions into the Portuguese cultural space.

The Berardo Museum collection is composed of renowned artists and artworks, as the museum:

presents the most significant artistic movements from the twentieth century to the present day [...] [Artists] are presented within the framework of the artistic movements which their works helped to define, through a chronological sequence that allows a journey through time. (Museu Berardo, n.d.)

What FACA proposed was not to curate an exhibition in the traditional way (e.g. invite artists to exhibit their artwork, or choose marginalised artworks to create an exhibition). These are the sort of actions 
that can only happen from within the museum-as Gulbenkian Museum did when it invited a curator and acquired women's artworks, for instance.

Instead, FACA proposed interpreting, through new marginal narratives, a selection of artworks and artists (centre) from the Berardo Museum's collection. Hence, FACA curated the contents of each talk, based on the existing collection and exhibition, and in dialogue with the audience (both specialists and the lay public), through a mediated conversation around each artwork. The artworks and artists' lives have always been read according to an alleged whiteness, masculinity and heterosexuality. Those who are not read as such are considered at the margins and as exceptions to the norm. FACA pulled the margins to the centre; here, the centre is considered not only the renowned artists but also the heteronormative and colonial readings of those artists and artworks. FACA disrupted those normative discourses, offering queer, postcolonial and feminist readings of those artworks and artists who have only been interpreted heteronormatively.

With no intention of erasing history, FACA aimed to pull the marginal narratives to the centre of the discussion by reading various, overlapping narratives of the collection's renowned artists. FACA had an authorial-curatorial-activist voice, because they chose among the artists and artworks of the museum collection and brought discourses that had been absent from the museum's official discourse on those artists and artworks. FACA frame their work as curatorial activism, inspired by Maura Rilley, and identify themselves as:

people who dedicated their curatorial endeavours almost exclusively to visual culture in, of, and from the margins: that is, to artists who are non-white, non-Euro-US, as well as women, feminist and queer-identified [people] [...] [that] have committed themselves to initiatives that are levelling hierarchies, challenging assumptions, countering erasure, promoting the margins over the centre, the minority over the majority, inspiring intelligent debate, dissemination knew knowledge and encouraging strategies of resistance - all of which offer hope and affirmation. (Reilly \& Lippard, 2018, p. 22)

FACA presented the proposal Bringing the margin to the centre to the museum's educational servicesthe department that coordinates all activities that relate to the public - which accepted and supported the implementation of the three-talk series (e.g. by making resources available and advertising). This museum department was approached easily for several reasons. First, FACA members have had professional ties with that department. Second, the educational services coordinator was open to the proposed themes. Third, the museum had already held exhibitions on female artists, on which some of the FACA members worked. FACA also presented their proposal to the Lisbon Feminist Festival (FFLx), which welcomed it. Talk 1 was integrated into the FFLx programme. Talk 2 was strategically scheduled on the same night as the PRIDE Arraial (an evening event), attracting that audience segment. Both talks were disseminated through FFLx. Talk 3, on 7 March 2020, was one of the last events to be held before the first lockdown in mid-March 2020. 


\section{The study and participants}

The first author, Rita Grácio, conducted a qualitative study of the audiences that attended Bringing the margin to the centre. This study consisted of participant observation at two talks, the application of an adapted version of the Personal Meaning Mapping technique (Falk \& Storksdieck, 2005), and semi-structured phone interviews with participants, several weeks after the talks.

At the beginning of each talk, Grácio presented herself and explained the aim of the research, and the voluntary, consensual and confidential nature of the participation, both in interviews and in the PMM. If visitors agreed to participate in interviews, they would leave their e-mail and/or phone number. The phone interviews took place between a few weeks and almost two months after the event, following Falk and Dierking's method (Falk \& Dierking, 2011). The interviews were recorded with the participants' permission. They were transcribed and anonymised, and kept confidential.

The Personal Meaning Mapping (PMM) was adapted. PMM is a form of concept mapping, created by John Falk and his team at the Institute for Learning Innovation, designed to assess changes in an individual's conceptualisation of a topic over time, usually before and after an experience in a museum or exhibition (Falk \& Storksdieck, 2005, p. 752). Before the talk started, each participant was given a sheet of paper on which a keyword ${ }^{3}$ was written on the centre of the page, and the participants were each provided with one colouring marker. Participants were asked to write down, using that colour (colour 1), a free-word association related to that keyword. It was explained that there were no right or wrong answers: the aim was to access participants' previous knowledge, thoughts and feelings about that keyword. Then, at the end of the talk, they would fill in that same sheet again, but with a different colour (colour 2). They could change what they had previously written (add, erase, complete, rephrase, etc.) as a way of tracing the changes in their understanding, position, feelings or thoughts towards that keyword. The PMMs were analysed and used as prompts during the interviews.

There were around 15 people in the first talk, and 35 people in the second. The attendees were mostly queer people, feminists and cultural mediators. The term 'participants' will be used for the people who attended the event, and the term 'interviewees' applies to people who were interviewed. We will refer to queer and non-queer interviewees; the former self-identify as LGBTQI+, and the latter do not.

In this paper, we will analyse Talk 2 , for several reasons. Talk 2 focused on queerness (whereas Talk 1 was broader in scope, addressing all the themes of the series); attendance figures were higher; and its audience was more diverse regarding age, race/ethnicity, educational background, place of origin (not just from Lisbon), activism engagement and experience and engagement with the arts, as well as previous relations with Berardo Museum.

Recruited from Talk 2, fifteen people were interviewed. All of these interviewees had higher education qualifications (nine BA, five MA, one PhD), and were between the ages of 23 and 59 (median age $=36$ ). They all self-identified as cisgender (two self-identified as cis men; the others self-identified as cis women); eight identified as non-queer and seven as queer.

The following section presents FACA's curatorial approach to Talk 2, followed by the thematic data analysis of the Talk 2 participant interviews in which the emic categories of interviewees were privileged. These interviews were also analysed through the lens of post-critical arts sociology (DeNora, 
2000). To ensure anonymity, interviewees' information that could reveal participants' identity was removed or replaced. Interviewees' names were replaced by pseudonymous.

\section{Talk 2: Queer identities at the Berardo Collection Museum}

In Talk 2, FACA aimed to revisit and reframe a number of works and artists through a tracing of queer history. Does sexual orientation matter? Can we associate non-queer artists with a queer universe? First, we must state that we propose a performative definition of gender and sexuality, outside binaries. Gender identities are performed, negotiated and sustained at the level of everyday interaction, and in ways that result in institutionalised practices. In situated contexts, people are 'doing gender' (West \& Zimmerman, 2009). Judith Butler describes heteronormativity as the norms and practices that construct heterosexuality as 'natural', and which also reinforce dichotomies of male/female, constructing 'feminine women' and 'masculine men' (Butler, 1990). Heteronormativity and homophobia play a role in the regulation of gender. The discourse of art history does not escape from heteronormativity, and the queer, homosexual, transgendered or drag pasts of some artists have yet to be explored.

The following artists were selected as the focus of Talk 2: Marcel Duchamp, Francis Bacon, David Hockney, Andy Warhol, Jean-Michel Basquiat and Keith Haring. The rationale for this choice was the following: Duchamp had a feminine alter ego, Rrose Sélavy, whose Fresh Widow piece was on display in the museum's Boîte en Valise. Bacon had issues of familiar rejection (a flawed person, both artist and Oedyphus, is presented in Oedyphus and the Spynx-After Ingres) and the male body, which FACA connected to Hockney's Picture Emphasizing Stillness. The representation of the male figures and the overt presentation of the queer identity of Hockney through his work, even during times of homosexual illegality, was the focus. Queerness was central to Warhol's production process, as was discussed in and later deleted from Gene Swenson's ArtNews interview with Warhol; the focus here lay with how the discovery of the full unedited interview can change the reading of any work by Warhol. FACA finished with the Factory 'offspring' that were presented in the collection, focusing on the AIDS visibility and activist actions of Keith Haring.

On 22 June 2019, FACA welcomed the participants at the museum hall, presenting themselves, the event and the museum, and inviting everyone to gather in the garden at the end of the talk to celebrate Laura's birthday with Andreia's home-baked cake (FACA's members). After everyone filled in their PMM, FACA gathered everyone around a TV set in one of the museum's rooms, and screened an excerpt from a Pedro Almodovar film. The debate opened with the question 'what is queer?'. After the debate, participants discussed the appropriation of the term 'queer', agreeing on how it evolved from an insult to an empowering label. The participants then moved to another room, where FACA facilitated a new conversation around the artwork and its artist, requesting the audience's participation. From room to room, this was how the event proceeded.

The following section presents the themes that emerged throughout the interviews. They are grouped in sections with the following rationale: interest in learning about queerness (motivations), the opinion about the selected artists (event content evaluation), the opinion of the event itself (event format 
evaluation), the impact of the event on the interviewees, and interviewees' opinions on the role of art museums in addressing marginal (queer) identities.

\section{An interest to learn about queerness}

The main reason interviewees were brought to this art museum was because of their interest in the event's theme: queerness.

Self-identified queer participants who were not especially fond of art came to the event because of their interest in the topic:

I liked it! Because I didn't understand anything about art, and I feel that I learned a little more. And I feel that, as I am now getting more involved in the queer culture, it also made me feel more integrated into that culture [...] It's like you are learning about your history, about your culture. (Amanda)

Queer people reframe the art museum as a non-binary, pedagogically rich site where they and more general audiences can learn about queer history, culture and artists. Parents we interviewed also revealed that they used this event at the museum in a pedagogical way, springing from its contents to teach concepts of gender and sexual diversity to their children, and educating them about gender equality.

Art lovers and artists/mediators (either queer or non-queer) were motivated to come to the event to learn about the (familiar) museum artworks or the artists from a different angle-the queer angle:

I really liked the theme [queer] itself, and the artists that were going to speak of, I liked it very much, and there was this theme, which I'm also interested in, queer, other sexual orientations, and the artists themselves, who are associated with other lifestyles. (Luana)

I've been wanting to return to the museum, and I thought it was interesting to have that queer perspective, I never thought about it when I was there before [...] I was not sure if there were queer artists. I found maybe one or two. It was really interesting they show only those artists and those artworks. I got to know the museum better. (Cláudia)

I wanted to see those artworks under a new light, see a new interpretation pulled out of it, dust off standard interpretations. And I liked it! (Marco)

\section{Opinions on the artists' selection}

Many interviewees shared that they enjoyed the selected artworks and/or artists, as well as learning about them. When asked, interviewees could easily refer to the artist(s) or the artwork(s) they enjoyed the most. Although most interviewees could not recall the names of the artworks, or were sometimes confused if the artwork was made by the artists they were mentioning, they all described in 
great detail the paintings themselves, and/or they would recall details about the artists' lives or the paintings' context-which they framed as what they had learned.

It must be noted that not all artworks were enjoyed for the sake of being queer. As one queer interviewee said, 'Regarding the artists, I liked more some, than others. But that is about my particular taste, and not about identity issues' (Nora).

One of the artists/mediators showed some concern regarding what they saw as an excessive focus on the artists' biographies, over the artwork itself, which could bias the understanding of art. On the other hand, another artist/mediator praised the fact that FACA had 'turned the artists into people. Artists are just people, made of flesh and bone' (Salete).

If we also consider these divergent audience opinions, we can see that the meaning of the work of art is not a matter of stimulus-response, neither is it freely appropriated (phenomenological). Even when the reading of an artwork is guided through a standpoint (which some might consider too biographical), others might consider that approach appropriate, or even reframe it (disentangling the biography from the artwork itself).

\section{More than artworks: talks, screenings and readings}

All interviewees related their enjoyment, and the fact that they were engaged, with FACA's communication and facilitation skills in the talks around the artworks. Interviewees highlighted how FACA related deep knowledge, passion, humour, clarity and friendliness when telling about the artworks, as well as (what the interviewees referred to as) their 'complementarity' as a trio. 'The communication between the three was super fun. I liked their dynamics, the way they were sharing', said Rute, a non-queer women artist.

The communication style of FACA was mentioned by one non-queer interviewee as a distinctive feature that made them comfortable throughout a feminist event: 'the way they are [...] they're nice, friendly, empathic [...] it really helps a lot' (Marco, non-queer man, artist/mediator).

When referring to the event (without being prompted) interviewees commented on how they enjoyed the fact that FACA brought other materials to the talk. Some found it innovative and refreshing to watch the Almodovar film excerpt in the museum, while others mentioned that they liked receiving a handout with Andy Warhol's uncensored interview, which FACA had translated into Portuguese. FACA asked volunteers among the participants to read the interview out loud, and some interviewees highlighted that moment, which took place by Andy Warhol's 'boxes', as one of the most emblematic moments. This shows that multimodality and material cultures of curatorial activism matter, enabling and constraining certain forms of engagement with artworks.

\section{More than words: a 'pleasant environment'}

Another reason participants gave for coming to the event was that some attendees were friends or acquaintances of FACA's members. Many people knew about the event through this personal and/or professional connection to FACA. These people attended the event because they were interested in the event itself and because they wanted to show support to FACA's work and 'to this kind of event'. 
Only three interviewees that came to the event did not know FACA or FACA's friends or acquaintances; these three interviewees came across the event online.

Most people referred to an enjoyable, familiar atmosphere, where people seemed to know each other. Indeed, many people of the people from the queer community who attended this talk came in small groups; others knew each other by sight or were acquaintances. This was acknowledged by all the interviewees, who all agreed that this familiarity created a 'pleasant environment', and 'helped to improve the talk's dynamic'.

The next interviewee summarises how FACA created this 'pleasant environment'-in the way FACA designed the activity, in the way the audience had a personal connection with them and also because many of the participants knew each other:

They had an informal language. They were not distant [...] they didn't treat people with distance. They managed to get people to talk, also because they knew some people [...] And the audience even gave very personal inputs on the topic [...]. (Salete)

From this interviewee's reaction, we see how museums are understood as formal spaces-for starters, where one should not talk, or at least, should only talk in a low volume. FACA transformed the museum, even temporarily, only through their presence, their talk and the people they brought along with them (curatorial performance).

For the queer community, the talks represented 'a safe space', with 'a lot of familiar faces'. As one queer interviewee said: 'it was a space where you're completely at ease, you can ask any question, regardless of the topic, and everyone was so diverse, there was a little bit of everything in that group, and I felt completely at ease' (Amanda).

The outsiders to the queer community also described how they enjoyed a 'pleasant environment', with 'so many different people'. As a non-queer woman, art lover, said: 'I observed a great empathy in the participants, and with the speakers [FACA], I think there was a great empathy among everyone' (Cidalina).

This bodily co-presence was key to the meaningful queer re-reading of the artworks and artists. As important as it is to tell the 'hidden' stories of LGBTQI+ lives in itself, it is also important to do so with/by/for the queer community. Not only for queer people but for non-queer people too.

\section{'Oh, I don't like to talk': The elephant in the room}

FACA highlighted several times 'this is not a tour, this is a conversation'. The curatorial work of FACA is inspired by a participatory approach to museum audiences, which goes against the traditional views of the museum as the authority in the museum collections' interpretation (Hooper-Greenhill, 2000), and aims to promote participatory behaviours among audiences.

However, this is also the aspect that was problematic or at least ambiguous for interviewees. Despite the 'pleasant environment' that was created, and despite the fact that all interviewees mentioned they felt they were given the opportunity (time and space) to talk and participate, most did not feel comfortable participating, often describing themselves as 'shy'. 
The discomfort had to do with talking about unknown themes, either to strangers or to a familiar audience. On the one hand, the queer interviewees, for whom art was the unknown theme, did not feel comfortable sharing their thoughts on art. As one interviewee said, 'OK, we were not supposed to know anything about art, but no one wants to look bad' (Conceição). On the other hand, the art lovers, artists and mediators, to whom queerness was the unknown theme, did not feel comfortable discussing queerness, a 'delicate topic', and talking publicly in front of strangers.

When people do not want to talk, they might even abandon the room - that was the case of an older white man, who left the group after the talk on the first artwork. Maybe the solution is to find other ways of talking; other ways of doing things without words. This was also why FACA prepared a collage workshop at the end of Talk 3.

\section{Queering art, queering the self}

This event impacted on the people who experienced it, in subtle ways: it made people experience queerness and art in different ways (both queer and non-queer people, art lovers and nonart lovers).

For queer interviewees who found art 'difficult' and who 'don't understand art', the event provided contextual cues that enriched the way art was experienced. The following interview excerpt illustrates this subtle but meaningful experience:

What they told us, did not change the way I saw the paintings. [...] I had zero education for the arts, my parents did not [educate me] [...] and I never educated myself into arts [...] and, at school, they never pulled me into the arts, so today, when I go to a museum, I feel like I'm there, as if I'm looking through a window, seeing something, but not really [...] I can't explain. What I felt today [...] It's not that they [FACA] changed the way I see the artworks, but they gave me a context, which I finally could relate to: 'Okay, with this context I can interpret what I am seeing', or at least, give some meaning to what I see. So, they did not change the way I saw the exhibits, but they gave vital information so that I could make some sense of what I was seeing. (Jéssica)

This interviewee illustrates the instances in which the love for art is produced or is absent, new ways in which adult non-art lovers can start to enjoy museums and how what was described as an empty look through a window, can become an artwork or a meaningful experience. If art museums want to attract more audiences to art, they can learn from this experience.

For participants who already enjoyed art (queer or not) prior to their visit, the series also changed the way they experience art:

I used to look at those same painting and didn't see my experience there [as a queer person] [...] I didn't identify myself! And now, if I see those paintings or other artworks [...] I will identify them in a different way, they will resonate with me. (Conceição) 
Through art, as mediated by this event, some people also described how they changed the way they thought of and experienced queerness. The following excerpts describe how queer people felt the event destabilised their identity categories, creating a self-reflective moment, or how, by confirming what they already knew, it empowered them:

I started thinking [...] at the end of the day, I started questioning my own identity: if I would recognise myself as queer or not. Because being part of [...] having an LGBT identity, or an L identity is quite different $[\ldots]$ it made me question it. (Nora)

Non-queer interviewees were confronted with heteronormativity, as the following excerpts illustrate: 'I realised all the associations I made with that word [queer], and I was struck by prejudices, and associations I had with that word that I was not aware of [...]' (Marco, non-queer man, artist/mediator).

Art acts as an active ingredient in the formation of the (gendered) self (DeNora, 2000). From these excerpts follows that a gendered reading of art shapes the way we see ourselves. At the same time, queer art can impact on the construction of a queer subjectivity, even for those who did not think of themselves as queer or who did not know about queer prejudice.

Taking a performative approach to identities, we can see how people negotiate gender identity through artistic taste, practice, production, consumption or mediation. By 'learning' about queerness, one learns about art. By 'learning' about art, one learns about queerness. The museum and its events can provide a powerful social environment for learning about both.

\section{The art museum as an informal and inclusive forum}

All the interviewees highlighted the importance of events taking place in museums that have a societal impact and the uniqueness of this initiative in the context of the Portuguese landscape. They supported the Berardo Museum for promoting this event, and all said they would recommend it to others. One of the interviewees who was not generally interested in art said she would be returning to the museum with other friends, to share with them what she learned during a series of talks there.

Moreover, the interviewees who were involved in activist organisations, as well as the artists/mediators, claimed that museums should promote a space to debate not only gender and sexuality issues but also other issues that are relevant to society. The following excerpt of interviewees (not involved in activism) reflect these visitors' expectations towards a museum, and how the event they took part in positively answered their expectations:

I think we should be at ease to discuss things at a museum. The museum should be inclusive. It does not mean the museum should choose sides. But it must promote debate. (Nora)

I think museums should make the most of the artists and artworks they have [...] This sort of event only gives visitors a reason to return. And for people who are going for the first time, have a much more useful perspective of what a visit to a museum of contemporary art can be. It's more dynamic! I think that the museum's goals are not for people to pay a one-time visit to the 
museums. But people only come back for thematic tours or new exhibitions. So they better work with their resources, and bring people back! (Luísa)

All the interviewees' opinions and suggestions show a great degree of reflexivity. As an artist said, 'I liked how they brought a non-institutional discourse to an institutional space' (Salete). Hence, the event organised by FACA, in terms of both content and format, can be used as a source for museums' organisational learning.

\section{Discussion}

Taking the expression used by one of the interviewees, and expanding on it, one can say that FACA was able to 'create a queer space, within the space of a museum'. We might wonder whether this may have the effect of ghettoising the LGBTQI+ audience. Do we run the risk of othering and/or essentialising either the artworks or the LGBTQI+ experience when doing a queer reading of the artworks and artists? From the data collected in this specific event, the answer points to no to all these questions. The queer community expects the museum to be 'an educational resource', not only for the queer community but also for others. On the other hand, outsiders to this community want to learn or transmit to their children lessons on gender and sexual diversity. These results are in line with other studies. Tselious (2013) argued that LGBTQI+ grassroots projects appealing to general visitors, and integrated within permanent exhibitions, constitute more inclusive curatorial practices than temporary exhibitions confined to a gallery space. FACA's collective curatorial activism shows that museums can become a forum where collections can be used to spur public debates on difficult, but relevant, societal issues.

It was FACA's 'emotional connection' and informal, multimodal approaches to displaying artworks that succeeded in engaging visitors and forging bonds between participants- most of whom knew each other and shared common interests, either in queerness or art -- during the discussion. The embodied co-presence of different people (affect) impacts on the whole experience, from the construction of subjectivities to the interpretation of art. FACA also opened up space for participation. FACA constructed a space to talk at the museum - not without trouble, as always happens when the museum becomes a 'contact zone' (Clifford, 1997). When the interviewees were asked to whom they would recommend this event, or what kind of person they envisioned coming to this event, it did not seem plausible to interviewees that a person who did not like either art or queerness could be interested. The unknown old white man who abandoned the event as soon as he realised what the event was about, seems to show the limits of the museum as a contact zone: the likely art lover and regular museum-goer did not stay for the topic of queerness. Furthermore, none of the interviewees even noticed his absence.

FACA's curatorial activism style (collective, participatory, emotional, embodied), and the abovementioned conditions that made this event possible, show that new narratives for the collection displays can make a difference, can make the museum more relevant for the participants and can make the museum more inclusive. 
This event raised awareness among cisgender visitors with heteronormative perspectives and provided a space for the counter-narratives of the queer community to thrive. This event attracted new museum visitors who may not have visited the museum otherwise. We can build from there. One interviewee explained that their parents could better grasp the idea of non-heterosexual identities, given that they had a connection to their queer child. We can see how backward intergenerational transmission is effective in changing prejudices and stereotypes. Maybe we could think of the art museum as a safe forum where difficult topics—queerness, racism, sexism, and other issues - can be collectively discussed and addressed.

\section{Lessons on how to be an inclusive organisation: gate-leaking}

This case study shows that art museums can promote gender equality and diversity, can be inclusive and can offer some lessons to other organisations on how to do so.

Curators, cultural mediators and museums as a whole are often seen as gatekeepers. Curatorial activism has been a way to loosen up this gatekeeping, and to push change. However, this push for change has mostly been from curatorial activists who are outsiders to the organisation. FACA is not a total stranger to the organisation, as it has professional ties to the museum. FACA were fully supported by the museum's educational departments, who, despite having less power in the organisational organigram, can act as catalysts for organisational change.

FACA represents gate-leaking', as opposed to gatekeeping: they make small breaches into the walls of the museum, making the museum leak, as the outside also leaks into the museum. This gateleaking could not have happened without the support of the museum's educational services, or without the connections to the Feminist Festival or PRIDE. FACA's 'connecting the dots' between the museum (through the educational services), PRIDE Arraial and the LGBTQI+ community, and the Lisbon Feminist Festival prompted gate-leaking. As paradoxical as it seems, connecting the dots enabled the leaking.

FACA operates in the liminal space between the private/institutional realm and the marginal/underground/counterculture. Its style of curatorial activism enabled the leaking between old and new narratives, art lovers and non-art lovers, queer and non-queer, and all the interstitial spaces and folds it opens, as it leaks.

\section{Acknowledgements}

The authors thank the Berardo Collection Museum, Cristina Gameiro and all the museum staff; the Lisbon Feminist Festival, the activists and all the participants in the talks. The authors also thank Rita Alcaire for her insightful comments.

\section{References}

Abrantes, P. and Roldão, C. 2019. 'The (mis)education of African descendants in Portugal: Towards vocational traps?,' Portuguese Journal of Social Science, 18(1), pp. 27-55. Available at: <doi: 10.1386/pjss.18.1.27_1> [Accessed 19 May 2020].

Alcaire, R. 2019. 'Do armário para fora 15 anos de "não te prives" e a importância dos arquivos queer,' TedxCoimbra, Coimbra, 29 October. 
Baldwin, J. H. and Ackerson, A. W. 2017. Women in the Museum: Lessons from the Workplace. Taylor \& Francis.

Baptista, J. and Boita, T. 2017. [Online]. 'Museologia e Comunidades LGBT: mapeamento de ações de superação das fobias à diversidade em museus e iniciativas comunitárias do globo,' Cadernos de Sociomuseologia, 54(10). Available at: <doi: 10.36572/csm.2017.vol.54.02>. [Accessed 14 April 2020].

Brulon, B. 2019. [Online]. 'Museus, mulheres e gênero: olhares sobre o passado para possibilidades do presente*,' Cadernos Pagu, (55), p. 1-28. Available at: <doi: 10.1590/18094449201900550015>. [Accessed 14 April 2020].

Butler, J. 1990. Gender trouble: feminism and the subversion of identity. London: Routledge (Thinking gender).

Cardoso, J. A. 2019. [Online]. 'Há um novo "percurso feminista" pela Colecção Moderna da Gulbenkian,' PÚBLICO, 30 May. Available at:

<https://www.publico.pt/2019/05/30/culturaipsilon/noticia/ha-novo-percurso-feminista-coleccaomoderna-gulbenkian-1874788>. [Accessed 22 May 2020].

Cascais, A. F. and Ana Cristina (eds.). 2004. Indisciplinar a teoria: estudos gays, lésbicos e queer. Lisbon: Fenda.

Clifford, J. 1997. 'Museums as contact zones,' in Routes: travel and translation in the late twentieth century. Edited by J. Clifford. Cambridge, MA: Harvard University Press, pp. 188-219.

DeNora, T. 2000. Music in everyday life. Cambridge: Cambridge University Press.

Falk, J. H. and Dierking, L. D. 2011. The Museum Experience. Walnut Creek, CA: Routledge.

Falk, J. H. and Storksdieck, M. 2005. 'Using the contextual model of learning to understand visitor learning from a science center exhibition,' Science Education, 89(5), pp. 744-778. Available at: <doi: 10.1002/sce.20078>. [Accessed 17 January 2020].

Hooper-Greenhill, E. 2000. 'Changing Values in the Art Museum: rethinking communication and learning,' International Journal of Heritage Studies, 6(1), pp. 9-31. Available at: <doi:

10.1080/135272500363715>. [Accessed 18 December 2019].

Lussenhop, A. 2018. 'Beyond the Male/female Binary: Gender Equity and Inclusion in Evaluation Surveys,' Journal of Museum Education, 43(3), pp. 194-207. Available at: <doi: 10.1080/10598650.2018.1484201>.[Accessed 5 March 2020].

Modest, W. 2012. 'WE HAVE ALWAYS BEEN MODERN: Museums, Collections, and Modernity in the Caribbean,' Museum Anthropology, 35(1), pp. 85-96. Available at: <doi: 10.1111/j.15481379.2011.01124.x>. [Accessed 18 December 2019].

Moutinho, M. 2019. Sociomuseologia: Ensino e Investigação. 1993-2018. Lisbon: Edições Universitárias Lusófonas.

Museu Berardo. n.d. Current exhibitions. Available at: <https://en.museuberardo.pt/exhibitions/current> [Accessed 28 September 2020].

Rechena, A. 2013. [Online]. 'Sociomuseologia e género: imagens da mulher em exposições de museus portugueses,' Cadernos de Sociomuseologia, 45(1). Available at:

<https://revistas.ulusofona.pt/index.php/cadernosociomuseologia/article/view/4551> [Accessed: 25 May 2020]. 
Rechena, A. and Furtado, T. V. 2019. 'Género na Arte: Dos museus à academia de belas-artes Estudos de caso de investigação artística,' Faces de Eva. Estudos sobre a Mulher, (EXTRA), pp. 245-260.

Reilly, M. and Lippard, L. 2018. Curatorial Activism: Towards an Ethics of Curating. 1st edition. New York: Thames \& Hudson.

Ribeiro, A. P. 2018. 'The impossible museum,' in Memoirs. Centre for Social Studies - University of Coimbra. Available at:

<https://memoirs.ces.uc.pt/ficheiros/4_RESULTS_AND_IMPACT/4.3_NEWSLETTER/MEMOIRS_ne wsletter_03_APR_en.pdf>.[Accessed 15 April 2020].

Sandahl, J. 2019. [Online]. 'Addressing Societal Responsibilities Through Core Museum Functions and Methods: The Museum Definition, Prospects and Potentials,' Museum International, 71(1-2), pp. iv-v. Available at: <doi: 10.1080/13500775.2019.1638016>. [Accessed 15 April 2020].

Santos, A. C. 2012. 'Disclosed and Willing: Towards A Queer Public Sociology,' Social Movement Studies, 11(2), pp. 241-254. Available at: <doi: 10.1080/14742837.2012.664904>. [Accessed 5 March 2020].

Tseliou, M.-A. 2013. 'Disruptive Paradigms in Museums and Galleries: Challenging the Heteronormative Frame,' The International Journal of Social, Political and Community Agendas in the Arts, 7(2), pp. 1-12.

Vaquinhas, I. 2014. 'Museus do feminino, museologia de género e o contributo da história [Women's museums, gender museology and the contribution of history],' Midas, (3). Available at: <doi: 10.4000/midas.603>. [Accessed 5 March 2020].

West, C. and Zimmerman, D. H. 2009. [Online]. 'Accounting for Doing Gender,' Gender \& Society, 23(1), pp. 112-122. <doi: 10.1177/0891243208326529 >. [Accessed 5 March 2020].

\section{Biographies}

Rita Grácio holds a PhD in Sociology from Exeter University. She's currently a postdoc for the project muSEAum (PTDC/EGE-OGE/29755/2017) at Lusófona University, Portugal.

Andreia C. Coutinho is a museum educator and illustrator. She has a BA in Fine Arts from FBAUL (2009) and an MA in Communication Design: Illustration from Kingston University London (2015). Coutinho has worked in museums since 2010, both in Portugal and in the UK; she is also a co-creator of Colectivo FACA, a curatorial activism collective based in Lisbon.

Laura Tecedeiro Sequeira Falé holds an MA degree in Political Philosophy (2015). She is a queer activist and educator and a co-creator of Colectivo FACA, a curatorial activism collective based in Portugal. Falé is a graduate student in Management and Finance at ISCTE-IUL.

Maribel Mendes Sobreira is an architect with an MA in Philosophy from the University of Lisbon (2016); she is also a PhD student at the University of Lisbon in the field of aesthetics and philosophy of art. Sobreira is a research member of the Centre of Philosophy at the University of Lisbon. She was 
a cultural mediator both at the Cultural Centre of Belém and at the Berardo Collection Museum in Lisbon. She is a co-creator of Colectivo FACA.

1 FACA is not an acronym, but roughly translates from Portuguese to "The Knife".

${ }^{2}$ Lisbon's Participatory Budgeting (PB) is a form of citizen's participation in the governance of the City of Lisbon, whereby citizens can decide on a fraction of the city's budget, by submitting proposals for the city and/or vote for the projects they would like to see included in the following year budget(https://op.lisboaparticipa.pt/o-que-e-o-op).

${ }_{3}^{3}$ The words have previously been agreed upon with FACA, and were based on the theme of each talk. PMM of Talk 1 used the word: 'Margins'; PMM of Talk 2 used the word 'Queer'. 